\title{
DEHIDRATACIJOS IR REHIDRATACIJOS HIPERTERMIJOS SĄLYGOMIS POVEIKIS AKTYVIAI SPORTUOJANČIŲ SUAUGUSIŲJŲ PERIFERINIAM IR CENTRINIAM NUOVARGIUI
}

\author{
Kazys Vadopalas, Marius Brazaitis, Albertas Skurvydas, Aleksas Stanislovaitis, Nerijus Eimantas, \\ Petras Minderis, Justinas Kudrevičius \\ Lietuvos kūno kultūros akademija, Kaunas, Lietuva
}

Kazys Vadopalas. Biomedicinos mokslų daktaras. Lietuvos kūno kultūros akademijos Taikomosios fiziologijos ir kineziterapijos katedros lektorius. Mokslinių tyrimų kryptis — raumenų fiziologija: hipertermijos ir dehidratacijos poveikis raumenų nuovargiui.

\begin{abstract}
SANTRAUKA
Tyrimo tikslas — nustatyti dehidratacijos ir rehidratacijos hipertermijos sqlygomis poveiki aktyviai sportuojančiuju centriniam ir periferiniam nuovargiui.

Tiriamieji - suauge aktyviai sportuojantys vyrai (n=10, amžius 21,1 $\pm 1,3 \mathrm{~m}$., küno svoris 70,46 \pm 6,54 kg, ūgis $174 \pm 5,3 \mathrm{~cm})$ ir suaugusios aktyviai sportuojančios moterys ( $n=8$, amžius 21,2 $\pm 2,4$ m., küno masé 60,88 $\pm 8,4 \mathrm{~kg}$, ügis 170,2 \pm 4,9 cm). Visi tiriamieji — vidutiniu nuotoliu bègikai, sportuojantys ne mažiau kaip 10 valandu per savaitę.

Atlikti trys tyrimai - vienas kontrolinis ir du eksperimentiniai. Vieno eksperimento metu buvo sukeliama organizmo ${ }^{\circ}$ dehidratacija hipertermijos sqlygomis (tiriamieji 45 minutes sèdejo panirę iki juosmens šiltoje vonioje, kurios vandens temperatūra $44 \pm 1^{\circ} \mathrm{C}$ ). Eksperimento metu tiriami vyrai vidutiniškai neteko 0,94 $\pm 0,15 \mathrm{~kg}(1,33 \pm 0,13 \%)$, moterys $0,62 \pm 0,18 \mathrm{~kg}(1,01 \pm 0,18 \%)$ kūno svorio. Kito eksperimento metu tokia pačia procedūra sukeliant hipertermija buvo atliekama peroralinè organizmo rehidratacija (per 1 valanda kas 6 minutes tiriamiesiems buvo duodama po $100 \mathrm{ml}$ (iš viso $1000 \mathrm{ml}$ ) $37^{\circ} \mathrm{C}$ fiziologinio $0,9 \% \mathrm{NaCl}$ tirpalo). Vyru svoris vidutiniškai padidejo 0,1 $\pm 0,42 \mathrm{~kg}(0,1 \pm 0,58 \%)$, moteru - 0,34 $\pm 0,18 \mathrm{~kg}(0,57 \pm 0,32 \%)$ kūno svorio. Nuovargis sukeltas atliekant maksimaliosios valingos jëgos (MVJ) izometrini krūvì, kuris tęsési 120 s: kas 15 s raumuo buvo stimuliuojamas elektros impulsu pluoštu (250 ms trukmès $100 \mathrm{~Hz}$ dažnio elektriniu impulsu serija (TT-100 Hz)). Registruotas raumenu MVJ momentas ( $N \cdot m)$, nevalinga raumenu susitraukimo jëga (sukelta TT-100 Hz stimuliacijos) ir raumenu centrinio aktyvavimo laipsnis (CAR).

Sukèlus dehidratacija ir atlikus rehidratacija hipertermijos salygomis vyru ir moteru rektalinè kūno temperatūra vidutiniškai padidejo $\sim 2^{\circ} \mathrm{C}(p<0,001)$. MVJ, TT-100 Hz ir CAR rodikliai tarp aktyviai sportuojančiu vyru ir moteru skirtingu eksperimentu metu reikšmingai nesiskyrè. Rehidratacija hipertermijos salygomis reikšmingai sumažino tiriamuju centrinį nuovargi, lyginant su dehidratacija hipertermijos salygomis. Tačiau šis rodiklis dehidratacijos ir rehidratacijos hipertermijos salygomis buvo nustatytas reikšmingai didesnis, lyginant su kontroliniu eksperimentu (t. y. CAR rodiklis, lyginant su pradine reikšme, 26\% sumažejo dehidratacijos eksperimento metu; rehidratacijos eksperimento - 42\%; kontrolinio tyrimo metu - 15\%). MVJ ir TT-100 Hz sukeltos jegos momento rodikliu kaita krūvio metu tarp eksperimentu reikšmingai nesiskyrè.
\end{abstract}

Raktažodžiai: izometrinis krūvis, raumenu centrinis aktyvavimo laipsnis, rektalinè temperatūra, pasyvus šildymas.

\section{IVADAS}

$\mathrm{L}$ iteratūroje nurodoma, kad aukšta kūno vidinè temperatūra pagreitina nuovargio atsiradimą fizinio darbo metu (Morrison et al., 2004). Kuri laiką buvo manoma, kad mechanizmas, paaiškinantis neuroraumenini nuovargi, hipertermijos sąlygomis gali kilti tiek dèl centrinès, tiek dèl periferinès nervų sistemos pokyčių (Kent-Braun, 1999). Tačiau M. M. Thomas ir kt. (2006) įrodè, kad hipertermija sumažina darbinguma, ir tai priklauso nuo centrinès nervų sistemos negalejimo pilnai aktyvuoti raumens esant aukštai $39^{\circ} \mathrm{C}$ rektalinei temperatūrai. Per sporto pratybas ir varžybas dažnai susiduriame su hipertermijos ir dehidratacijos reiškiniais, kurie riboja neuroraumenini darbą ir neleidžia pasiekti gerų sportinių rezultatų. Iki šiol literatūroje nepavyko rasti duomenų, irrodančių, 
koki termini poveiki patiria aktyviai sportuojantys vyrai ir moterys, pasyviai sukèlus organizmo dehidrataciją ir rehidrataciją hipertermijos sąlygomis, kaip tai veikia sportininkų atsparumą centriniam nuovargiui, atliekant didžiausio intensyvumo izometrinị kartotinị fizinị krūvị.

Hipertermijos metu temperatūrinè homeostazè didina prakaitavimą ir širdies kraujagyslių sistemos darbą (Armstrong, 2000). Priežastis, dèl kurios gali sumažèti raumenų darbingumas, yra skysčių netekimas organizme - dehidratacija (Armstrong, 2000). Hipertermijos metu netekus $2 \%$ kūno svorio, žmogaus ištvermè sumažeja $22 \%$, o netekus $4 \%$ - net 48\% (Armstrong et al., 1992). Dirbant karšto klimato sąlygomis ar atliekant didelio intensyvumo ilgos trukmès fizinius pratimus, žmogus vidutiniškai netenka $0,8-1,41 / \mathrm{h}$ prakaito (Armstrong, 2000). Aklimatizuoti žmonès kartu su prakaitu netenka apie $0,8-2,0 \mathrm{~g} \mathrm{NaCl} / 1$, o neaklimatizuoti - apie 3,0-4,0 g NaCl / 1 (Armstrong, 2000). Pastarieji elektrolitai žmogaus organizme yra laikomi pagrindiniais, kurių dẻka palaikoma vandens pusiausvyra viduląstelineje ir tarpląstelineje terpeje, nervinis laidumas, ląstelinis metabolizmas ir kraujo tūris osmoreguliacija ir spaudimas (Armstrong, 2000). Ankstesnio mūsų tyrimo metu nustatème, kad rehidratacija hipertermijos sąlygomis neigiamai veikia ir dar labiau padidina centrini nuovargi atliekant 2 minučiu maksimalų izometrinị krūvị (Vadopalas ir kt., 2007 a, b). Manytume, kad rehidratacija hipertermijos sąlygomis turètu sumažinti aktyviai sportuojančiujų centrinį nuovargi dèl geresnès širdies ir kraujagyslių sistemos adaptacijos prie hipertermijos ir fizinių krūvių, geresnio vandens ir elektrolitu santykio prakaite, viduląstelineje ir tarpląstelineje terpëje nei nesportuojančiujų.

Manoma, kad vyrų ir moteru fiziologinis atsakas i fizinio krūvio sukeltą šilumini stresą taip pat turètu skirtis (Moran et al., 1999). Keletas tyrimų parode, kad kai susiduriama su dideliu šiluminiu stresu ir fizine veikla, moterų organizmo termoreguliacija yra mažiau veiksminga nei vyrų (McLellan, 1998). Moterys, lyginant su vyrais, yra mažesnio širdies ir kraujagyslių, kvėpavimo sistemų pajègumo, turi daugiau kūno riebalinio audinio, mažesnę kūno masę, mažesnị kūno paviršiaus plotą ir didesnį santykị tarp kūno paviršiaus ploto ir masès, jų kūne yra santykiškai mažiau vandens (Lindle et al., 1997). Be to, hormoninè estrogeno ir progesterono kaita menstruacinio ciklo metu gali paveikti moteru fizini darbingumą ir toleranciją fizinio krūvio sukeltam šiluminiam stresui (Rothchild, Barnes, 1952; Sato et al., 1989). Atlikdamos mažo arba vidutinio inten- syvumo ištvermės reikalaujančius izometrinius pratimus moterys yra ištvermingesnès nei vyrai (Fulco et al., 1999; Ditor, Hicks, 2000). Mechanizmas, aiškinantis ši ištvermès skirtumą laiko atžvilgiu, nėra iki galo aiškus (Hunter, Enoka, 2001). Tačiau yra dvi labiausiai paplitusios hipotezès: pirma jègos skirtumas atsiranda dèl skirtingos raumenu masès, antra - dèl skirtingos raumenų aktyvacijos (Clark et al., 2003). Vyrai turi didesnę greituju raumeninių skaidulų masę negu lètujų. Moteru šis santykis - priešingas (Staron, Hagerman, 2000; Bamman et al., 2003). Manytume, kad atliekant ištvermès reikalaujantį darbą dèl palankesnès raumenų kompozicijos aktyviai sportuojančių moterų periferinis nuovargis turètų būti mažesnis nei vyrų, o dèl mažiau veiksmingos termoreguliacijos centrinis nuovargis didesnis, lyginant su vyrais.

Tyrimo tikslas - nustatyti dehidratacijos ir rehidratacijos hipertermijos sąlygomis poveiki aktyviai sportuojančiujų centriniam ir periferiniam nuovargiui.

\section{TYRIMO METODIKA}

Tiriamieji - suaugę aktyviai sportuojantys vyrai (n $=10$, amžius $21 \pm 1,3 \mathrm{~m}$., kūno svoris $70,46 \pm 6,54 \mathrm{~kg}$, ūgis $174 \pm 5,3 \mathrm{~cm})$ ir suaugusios aktyviai sportuojančios moterys $(\mathrm{n}=8$, amžius 21,2 $\pm 2,4$ m., kūno masė $60,88 \pm 8,4 \mathrm{~kg}$, ūgis $170,2 \pm 4,9 \mathrm{~cm})$. Visi tiriamieji - vidutiniu nuotoliu bėgikai, sportuojantys ne mažiau kaip 10 valandu per savaitę. Visos moterys tirtos po mènesinių iki menstruacinio ciklo 12 dienos, kai jų ašinè temperatūra buvo žemiausia (folikulinès fazès metu) (Bauman, 1981; Horvath et al., 1982). Tiriamieji buvo supažindinti su tyrimo tikslais, procedūra ir galimais nepatogumais. Norą dalyvauti tyrime jie patvirtino raštu. Tyrimas atliktas laikantis 1975 m. Helsinkio deklaracijoje priimtų principu dèl eksperimentų su žmonèmis etikos. Tyrimo protokolas aptartas ir patvirtintas Kauno regioniniame biomedicininiu tyrimų etikos komitete (Protokolo Nr. 130 / 2005; Leidimo Nr. BE-2-54).

Dinamometro nustatymas ir padèties sureguliavimas. Izometriné blauzdos tiesiamujų raumenų jèga vertinta naudojant izokinetini dinamometra (Biodex Medical System 3, New York). Tiriamieji buvo sodinami i dinamometro irenginio kèdę, testuojama dešinè koja. Prie dinamometro pritvirtinamas papildomas blauzdos tvirtinimo itaisas. Nustatoma kelio anatominè sąnario ašis ir sulyginama su dinamometro dinaminès apkrovos mazgo ašimi. Nustatoma visa kelio sąnario amplitudè. Mažinant 
viso kūno inercinị svyravimą, tiriamasis apjuosiamas pečių, liemens ir šlaunies diržais. Blauzda sutvirtinama diržu $4 \mathrm{~cm}$ virš kulnakaulio gumburo ties apatiniu trečdaliu, koja fiksuojama per kelio sąnari $90^{\circ}$ ir $120^{\circ} \mathrm{kampu}$ (blauzda ištiesta $180^{\circ}$ kampu). Pasveriama tada, kai ji fiksuota $108^{\circ} \pm 5^{\circ}$ kampu (sunkio jègos momentu). Registruotas maksimaliosios valingosios jègos momentas $(\mathrm{N} \cdot \mathrm{m})$ ir nevalinga (elektrinių impulsų sukelta) jèga.

Eksperimento eiga. Prieš eksperimentą tiriamieji buvo supažindinami su procedūra. Ne anksčiau kaip po savaitès tiriamieji atliko kontrolini arba vieną iš dviejų eksperimentinių tyrimų.

Kontrolinio tyrimo metu tiriamieji po neintensyvios pramankštos - 10 minučių bègimo (pulsas matuojamas visos pramankštos metu, pulso dažnis - 110 - 130 tv. / min) - buvo sodinami i izokinetinio dinamometro kẻdę ir atliko krūvi (aprašymą žr. MVJ-2 min), tik pasyviai raumenu nešildant.

Pirmas eksperimentinis tyrimas nuo kontrolinio skyrèsi tuo, kad jo metu vietoj pramankštos buvo pasyviai sukeliama dehidratacija hipertermijos sąlygomis. Antro eksperimentinio tyrimo metu pasyviai sukèleme hipertermija — buvo taikoma peroralinė organizmo rehidratacija, t. y. per 1 valandą kas 6 minutes tiriamiesiems buvo duodama po $100 \mathrm{ml}, 37^{\circ} \mathrm{C}$ (kūno temperatūros) fiziologinio $0,9 \% \mathrm{NaCl}$ tirpalo.

Testavimo eiga. Taikant pasyvaus šildymo metodiką tiriamieji, atvykę i laboratoriją, 30 minučiu ramiai sẻdèdavo iprastinès temperatūros kambaryje $\left(20-22^{\circ} \mathrm{C}\right)$. Paskui matuojama ju rektalinè temperatūra ir atliekamas kontrolinis MVJ matavimas, t. y. darant 2 minučiu pertrauką atliekami trys maksimalūs valingi raumens susitraukimai tiesiant blauzdą per kelio sąnari $120^{\circ}$ fiksuotu kampu (raumens susitraukimo trukmè 5 s). Maždaug 2-3 šių susitraukimų sekundę keturgalvis šlaunies raumuo buvo stimuliuojamas $100 \mathrm{~Hz}$ dažnio ir $250 \mathrm{~ms}$ trukmès elektrinių impulsų serija. Paskui kojos buvo pasyviai šildomos, iš karto po šildymo vèl matuojama rektalinè temperatūra. Išlipus iš vonios, ne vèliau kaip po 5 minučių, tiriamieji buvo sodinami i dinamometro kẻdę ir atliko 2 minučių maksimalų valingą izometrini raumenų susitraukimą. Krūvio metu tiriamieji vilkejjo šiltą ilgą sportinę aprangą, buvo užsidejję pirties kepurę (hipertermijai išlaikyti eksperimentinių tyrimų metu). Abiejų eksperimentinių tyrimų pabaigoje (praejus vienai minutei po krūvio) buvo matuojama rektalinè temperatūra (hipertermijai kontroliuoti).
Maksimalus valingos jëgos izometrinis krūvis (MVJ-2 min). MVJ-2 min krūvis truko 2 minutes, tiriamieji buvo sodinami i izokinetinio dinamometro kèdę ir ant odos, ties keturgalvio šlaunies raumens distaliniu ir proksimaliniu trečdaliais, buvo fiksuojami trys $6 \times 12 \mathrm{~cm}$ anglimi dengti guminiai elektrodai, prieš tai plonu sluoksniu padengti specialiu geliu. Krūvio metu 3, 14, 29, 44, 59, 74, 89, 104 ir 119 sekundę buvo taikoma iterptinè šlaunies nervo elektrostimuliacija (naudojama $250 \mathrm{~ms}$ trukmès $100 \mathrm{~Hz}$ dažnio elektrinių impulsų serija TT-100 Hz), sukelta naudojant stimuliatoriu (modelis MG440, Medicor, Budapest, Hungary). Elektrostimuliacijos metu itampos dydis sieke 85-105 V. Kas trisdešimtą MVJ-2 min sekundę, t. y. 30, 60, 90 ir $120 \mathrm{~s}$, tiriamieji trumpam $(\sim 3 \mathrm{~s})$ nutraukdavo darbą atpalaiduodami šlaunies raumenis, ir šios pertraukos metu buvo atliekama kontrolinė TT-100 Hz elektrostimuliacija. Po šio stimulo tiriamieji toliau tęsè MVJ-2 min krūvį. Registruotas MVJ momentas $(\mathrm{N} \cdot \mathrm{m})$, ivertinamas centrinès aktyvacijos laipsnis (CAR), nusakantis dirbančiu raumenų valingos aktyvacijos dydi (Enoka, 2002). CAR(\%) = MVJ / (MVJ + elektrinis impulsas) $\times 100$ (Bilodeau, 2006; Behm et al., 2001). Kuo didesnis CAR, tuo mažesnis valingos raumenų aktyvacijos rezervas. Tiriamasis krūvio metu buvo motyvuojamas verbaliniu būdu, suteikiant jam vizualią jègos signalo kitimo informacija.

Noreddami palyginti išugdomos jẻgos dydi tarp vyrų ir moterų, skaičiavome išugdytos jègos dydžio (vertinamo niutonmetrais), tenkančio vienam kilogramui kūno masès $(\mathrm{kg})$, santyki $=$ MVJ $(\mathrm{N} \cdot \mathrm{m}) /$ kūno masè $(\mathrm{kg})$.

Pasyvaus šildymo metodika. Tiriamieji sèdèdami 45 minutes laikè kojas šiltoje vonioje, kurios vandens temperatūra $44 \pm 1{ }^{\circ} \mathrm{C}$, kambario temperatūra $20-22^{\circ} \mathrm{C}$. Šildymo metu jie negalèjo vartoti jokiu gèrimu ar naudoti dirbtinio vésinimo irenginių. Vandens temperatūra buvo matuojama vandens termometru (Brannan Floating Thermometer, UK), patalpos - oro termometru (TFA Digital Thermo-Hygrometer, UK).

Rektalinès temperatūros matavimo metodika. Rektalinè temperatūra buvo matuojama zondu, apvilktu silikonine guma su imontuotu termodavikliu (Ellab, tipas Rectal probe, Denmark). Tiriamasis prieš pasyvų šildymą ir po jo, t. y. apie dvi minutes, ivesdavo zondą su termodavikliu $i$ išeinamają angą (laikas $10 \mathrm{~s}$, gylis $12 \mathrm{~cm}$ ) (Prou$1 x, 2003)$. Po naudojimo zondas su termodavikliu buvo sterilizuojamas autoklave. 
Širdies susitraukimo dažnio matavimas. Prieš kiekvieną eksperimentini tyrimą ir pasyvaus šildymo metu širdies susitraukimų dažnis (ŠSD) buvo registruojamas 5 sekundžiu intervalais pulso matuokliu (S-625X, Polar Electro, Kempele, Finland).

Fiziologinio streso (šilumos) indekso (FSI) matavimo metodika. FSI buvo skaičiuotas pagal formulę (Moran et al., 1998):

$$
\begin{aligned}
& \text { FSI }=5\left(\mathrm{~T}_{\text {rektalinè } \mathrm{t}}-\mathrm{T}_{\text {rektalinè } 0}\right) \times(39,5- \\
& \left.-\mathrm{T}_{\text {rektalinè } 0}\right)^{-1}+\left(\check{S} \mathrm{SD}_{t}-\breve{S S S D}_{0}\right) \times\left(180-\breve{\mathrm{S} S D}_{0}\right) \text {, }
\end{aligned}
$$

FSI vertinimas: streso nėra arba labai mažas ( $0-2$ balai), žemas ( $3-4$ balai), vidutinis ( $5-6$ balai), aukštas ( $7-8$ balai) ir labai aukštas $(9-10$ balų).

Rehidratacija. Didžiausias skysčių kiekis, kuri fiziškai aktyvių žmonių organizmas gali pasisavinti, yra apie 0,8-1,2 1/ h (Coyle, Hamilton, 1990). Norint atgauti prarastą skysti, tiriamiesiems prieš 15 minučiu iki pasyvaus šildymo buvo duodama gerti $37^{\circ} \mathrm{C}$ (kūno temperatūros) fiziologinio $0,9 \% \mathrm{NaCl}$ tirpalo. Per 60 minučiu tiriamieji lètai išgerdavo $1000 \mathrm{ml}$ skysčio (po $100 \mathrm{ml}$ kas 6 minutes). Prieš tyrimą ir po jo nuogi vyrai ir moterys (sausu kūnu) buvo sveriami elektroninėmis svarstyklèmis „Tanita TBF 300“ (JAV). Nustatytas svorio skirtumas parodè prarasto skysčio kieki. Tiriamieji laikotarpiu tarp svèrimų negalëjo šlapintis ir vartoti skysčių.

Matematinè statistika. Buvo skaičiuojami rodikliu aritmetiniai vidurkiai ir standartiniai nuokrypiai. Poveikio reikšmingumas tarp lyties, eksperimento ir laiko buvo nustatomas naudojant triju veiksnių dispersinę analizę. Kai buvo nustatomas statistiškai reikšmingas poveikis, kartotiniams palyginimams skaičiuoti taikytas Post hoc testas ir Bonferroni korekcija. Skirtumas statistiškai reikšmingas, kai $\mathrm{p}<0,05$.

\section{REZULTATAI}

Sukèlus dehidrataciją hipertermijos sąlygomis vyru rektalinè kūno temperatūra vidutiniškai padidèjo nuo $37,38 \pm 0,25$ iki $39,36 \pm 0,32^{\circ} \mathrm{C}$ $(\mathrm{p}<0,001)$, moteru - nuo $37,54 \pm 0,24$ iki $39,62 \pm 0,30^{\circ} \mathrm{C}(\mathrm{p}<0,001)$. Reikšmingo skirtumo tarp vyru ir moteru rezultatų nenustatyta $(\mathrm{p}>0,05)$. Tiriant dehidrataciją hipertermijos sąlygomis, vyrai vidutiniškai neteko $0,94 \pm 0,15 \mathrm{~kg}$ $(1,33 \pm 0,13 \%)$ kūno svorio ( $I^{\circ}$ dehidratacija), moterys $-0,62 \pm 0,18 \mathrm{~kg}(1,01 \pm 0,18 \%)\left(\mathrm{I}^{0} \mathrm{de}-\right.$ hidratacija). Moterys vidutiniškai neteko $0,32 \mathrm{~kg}$ mažiau negu vyrai $(p<0,001)$. Atlikus peroralinę rehidrataciją hipertermijos sąlygomis, tiriamų vyru ir moterų rektalinès kūno temperatūros pokytis reikšmingai nesiskyrè. Vyrų svoris vidutiniškai padidejo $0,1 \pm 0,42 \mathrm{~kg}$, ir tai sudare $0,1 \pm 0,58 \%$ jų kūno svorio, moteru - $0,34 \pm 0,18 \mathrm{~kg}$, ir tai sudarè $0,57 \pm 0,32 \%$ jų kūno svorio. Pastarieji rodikliai rodo, kad buvo atlikta pilna organizmo rehidratacija. Išanalizavus fiziologini karščio streso indeksą (10 balų sistema) nustatyta, kad tiriamieji patyrè vidutinio ir aukšto lygio fiziologini stresą: vyrų dehidratacijos tyrimo metu $-7,40 \pm 1,21$, rehidratacijos $-6,77 \pm 0,81$, moteru atitinkamai $-8,10 \pm 1,01 ; 7,68 \pm 0,91$. Reikšmingai patikimo skirtumo tarp vertinamų būsenų rodikliu nenustatyta $(p>0,05)$.

Santykinė MVJ 3 krūvio sekundę reikšmingai sumažèjo $(p<0,001)$ ir nepriklausè nuo eksperimento pobūdžio, t. y. kontrolinio eksperimento metu, dehidratacijos ar rehidratacijos hipertermijos sąlygomis (1 pav.). Dispersinè analizė atskleidè, kad santykinè MVJ priklausè nuo laiko $(p<0,001)$, lytis tam itakos neturèjo $(p>0,05)$.

Visu trijų tyrimu metu TT- $100 \mathrm{~Hz}$ sukelta nevalinga jèga sumažèjo jau 60-ą sekundę nuo krūvio pradžios $(\mathrm{p}<0,001)(2 \mathrm{pav}$.$) . Dispersinè analizė$ atskleide, kad TT-100 Hz sukelta nevalinga jèga, tenkanti vienam kilogramui kūno masès, tiek sportuojančių vyru, tiek moterų reikšmingai nesiskyrẻ visų trijų eksperimentų metu ( $\mathrm{p}<0,001)$.

Per visus tris tyrimus CAR sumažèjo $(\mathrm{p}<0,001)$ jau trečią krūvio sekundę, ir šis sumažejjimas išliko statistiškai reikšmingas iki krūvio pabaigos (3 pav.) Lygindami sportuojančiuc vyru ir moteru CAR atliekant MVJ-2 min triju eksperimentu metu reikšmingu pokyčių nenustatème $(\mathrm{p}>0,05)$. Kontrolinio tyrimo metu CAR pakito mažiausiai. Dehidratacijos hipertermijos sąlygomis CAR sumažèjo daugiausia, lyginant su kontrolinio tyrimo ir rehidratacijos hipertermijos sąlygomis reikšmėmis. Rehidratacijos hipertermijos salygomis rezultatai parode, kad CAR krūvio pabaigoje buvo $15 \%$ didesnis, lyginant su dehidratacija hipertermijos sąlygomis. Dispersinè analizè atskleidè, kad CAR pokytis krūvio metu priklause nuo laiko $(\mathrm{p}<0,001)$ ir nepriklause nuo lyties bei sąveikos tarp šių veiksnių $(p>0,05)$.

Vyrų širdies susitraukimų dažnis pasyvaus šildymo metu padidejo $\sim 60,8$ tv. / $\min (\mathrm{p}<0,001)$, rehidratacijos — $\sim 47,8$ tv. / min ( $<<0,001)$, hipertermijos tyrimo metu moterų ŠSD padidejo $\sim 80 \mathrm{tv}$. / min 
1 pav. Sportuojančių vyrų ir moterų maksimaliosios valingos jẻgos, tenkančios vienam kilogramui kūno masès, rodikliai atliekant $\mathrm{MVJ}-2 \mathrm{~min}-$ tiesiant blauzdą per kelio sąnarị fiksuotu $120^{\circ}$ kampu
Pastaba. $* * *$ - pokytis, lyginant su pradine reikšme $(\mathrm{p}<0,001)$. A - kontrolinių tyrimų metu, B dehidratacijos ir $\mathrm{C}$ - rehidratacijos hipertermijos sąlygomis.

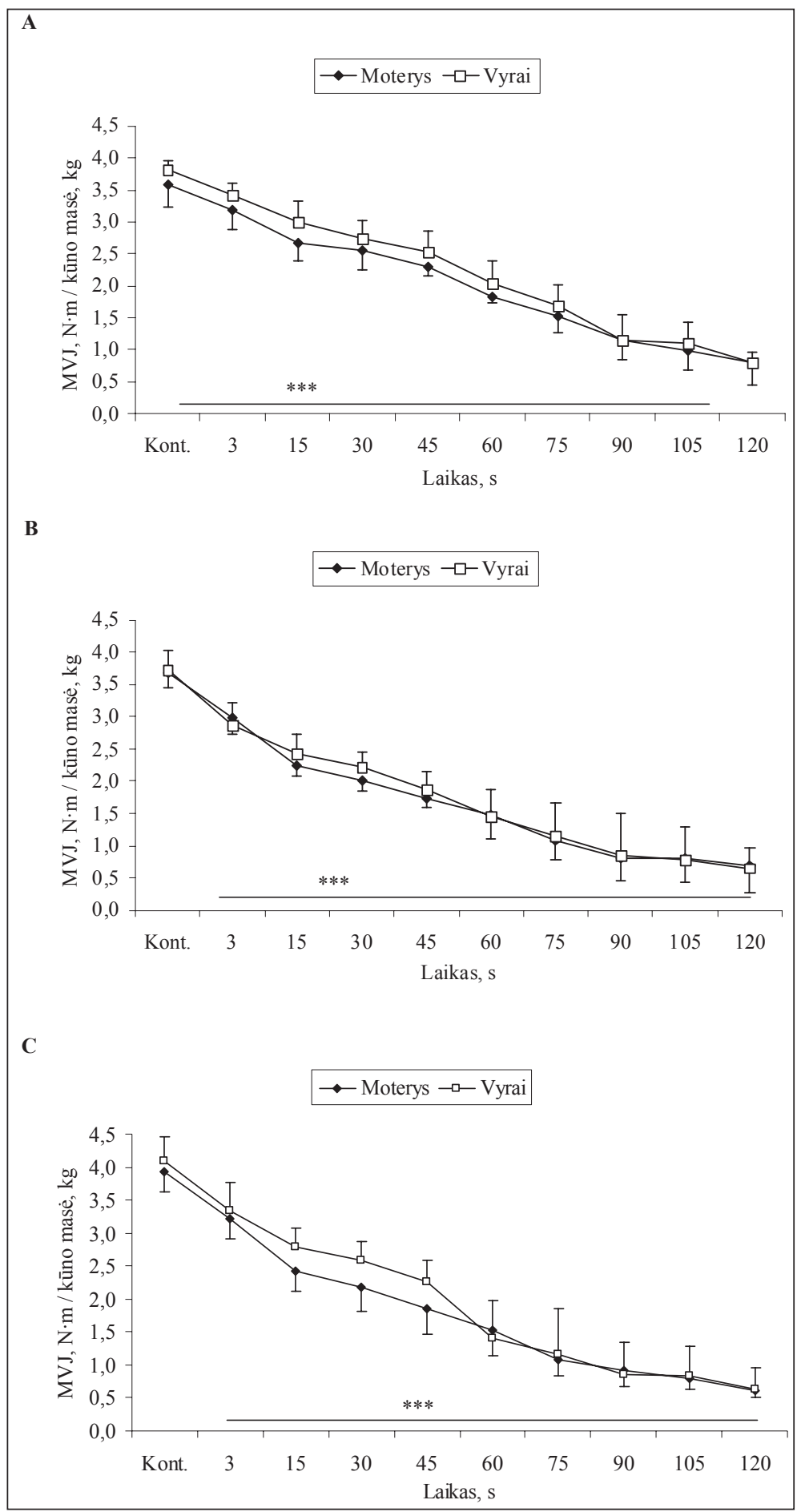

$(\mathrm{p}<0,001)$, rehidratacijos $-\sim 65,9$ tv. $/ \mathrm{min}$ ( $\mathrm{p}<0,001)$, lyginant su pradine reikšme. İdomu pažymèti, kad rehidratacjos pabaigoje tiek vyru, tiek ir moteru ŠSD buvo nereikšmingai mažesnis negu dehidratacijos hipertermijos sąlygomis.

\section{REZULTATŲ APTARIMAS}

Šiuo tyrimu nustatėme: rehidratacija hipertermijos sąlygomis padidino sportuojančiu vyrų ir moterų dirbančiujų raumenų valingą aktyvaciją, lyginant su dehidratacija hipertermijos sąlygomis, tačiau buvo nustatyta mažesnè, lyginant su kontrolinio tyrimo reikšmèmis. Santykinè maksimaliosios valingos jëgos ir elektros impulsų sukeltos jëgos momento rodiklių kaita krūvio metu tarp eksperimentų reikšmingai nesiskyrè. Centrinis aktyvacijos laipsnis, taip pat santykiniai maksimaliosios valingosios jègos ir elektros impulsų pluošto sukeltos nevalingos raumenų susitraukimo jẻgos rodikliai reikšmingai nesiskyrè tarp vyrų ir moterų.

Panašaus tyrimo metu $\mathrm{K}$. Vadopalas kartu su bendraautoriais (2007 a, b), taikydami pasyvaus raumenų šildymo metodiką, sukèlè aktyviai ne- 


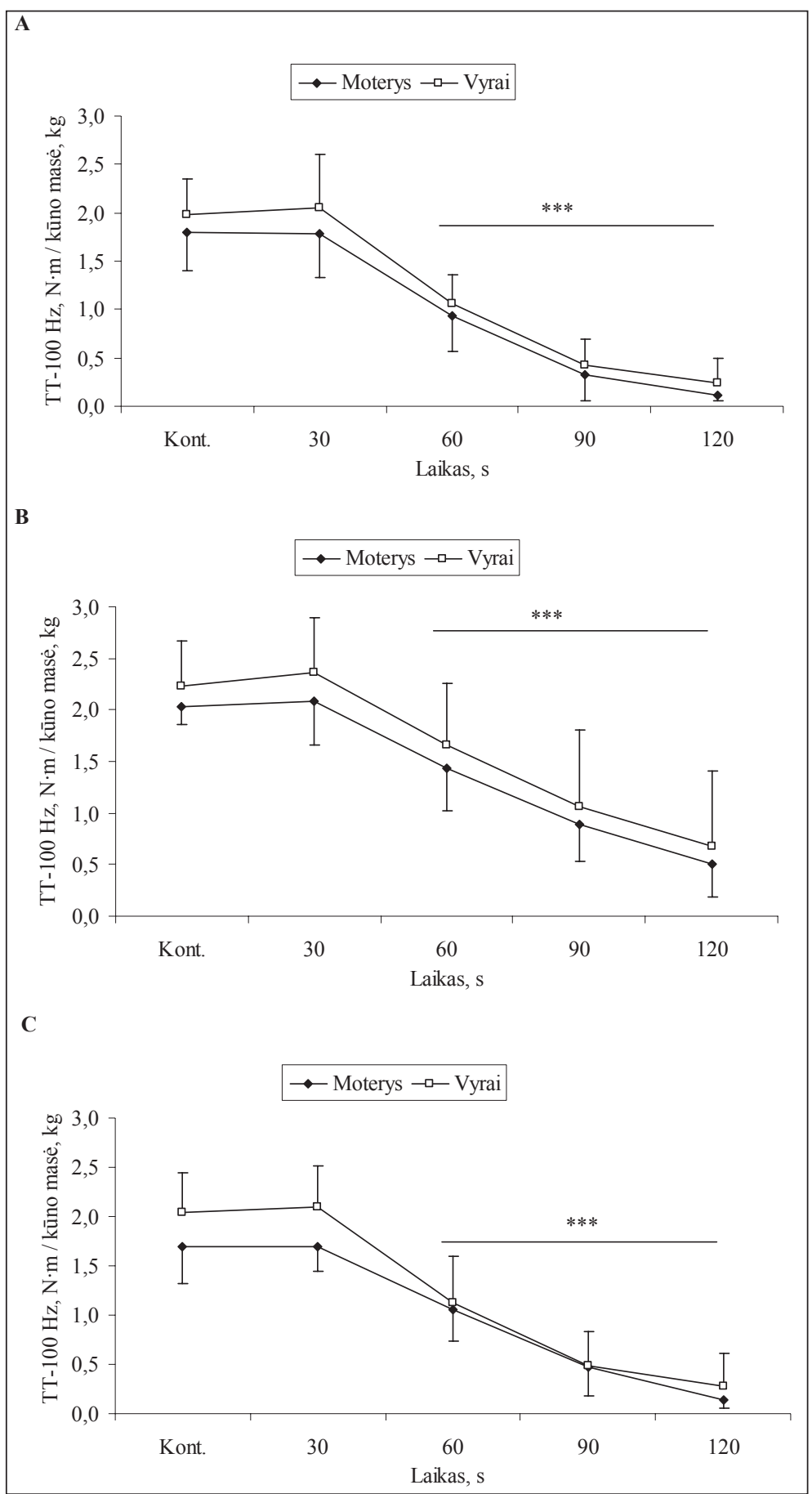

2 pav. Sportuojančių vyrų ir moterų nevalingos (TT-100 Hz sukeltos) jègos, tenkančios vienam kilogramui kūno masès, rodikliai, atliekant MVJ2 min — tiesiant blauzdą per kelio sąnarị fiksuotu $120^{\circ}$ kampu

Pastaba. $* * *-$ pokytis, lyginant su pradine reikšme $(\mathrm{p}<0,001)$. A - kontrolinių tyrimų metu, B dehidratacijos ir $\mathrm{C}$ - rehidratacijos hipertermijos sąlygomis.

sportuojančių vyrų ir moterų organizmo hipertermiją ir $\mathrm{I}^{\circ}$ dehidrataciją. Tuo pačiu tyrimu jie nustate, kad rehidratacija hipertermijos sąlygomis neigiamai veikia ir dar labiau padidina aktyviai nesportuojančių asmenu centrini nuovargi atliekant 2 minučių maksimalų izometrinį krūvị. Šiuo tyrimu nustateme, kad rehidratacija hipertermijos sąlygomis padidino sportuojančių vyrų ir moteru dirbančiujų raumenų valingą aktyvaciją, lyginant dehidratacijos rodiklius hipertermijos salygomis, tačiau buvo mažesnè, lyginant su kontrolinio tyrimo reikšmėmis. Rehidratacijos eksperimento metu netektam skysčiui atgauti tiriamieji gèré $37^{\circ} \mathrm{C}$ (kūno temperatūros) fiziologinị $0,9 \% \mathrm{NaCl}$ tirpalą. Tyrimo metu atlikus peroralinę rehidrataciją tiriamieji iki maksimalaus krūvio pradžios visiškai atgavo iš organizmo pašalintą skystį. Krūvio pabaigoje nustatytas $15 \%$ didesnis CAR, t. y. atliekant MVJ-2 min buvo sumažintas centrinis nuovargis. Galima manyti, kad tai iš dalies priklauso nuo fiziologinio $0,9 \% \mathrm{NaCl}$ tirpalo, jo patekimo i kraujotakos sistemą. Aklimatizuoti žmonès kartu su prakaitu netenka apie $0,8-2,0 \mathrm{~g} \mathrm{NaCl} / 1$, o neaklimatizuoti apie 3,0-4,0 g NaCl / 1 (Armstrong, 2000). Pastarieji elektrolitai žmogaus organizme yra laikomi pagrindiniais, kurių dèka vyksta van- 
3 pav. Sportuojančių vyrų ir moterų centrinès aktyvacijos santykis (CAR) atliekant MVJ-2 min tiesiant blauzdą per kelio sąnarị fiksuotu $120^{\circ}$ kampu
Pastaba. $* * *-$ pokytis, lyginant su pradine reikšme $(\mathrm{p}<0,001)$. A - kontroliniu tyrimu metu, B dehidratacijos ir $\mathrm{C}$ - rehidratacijos hipertermijos sąlygomis.

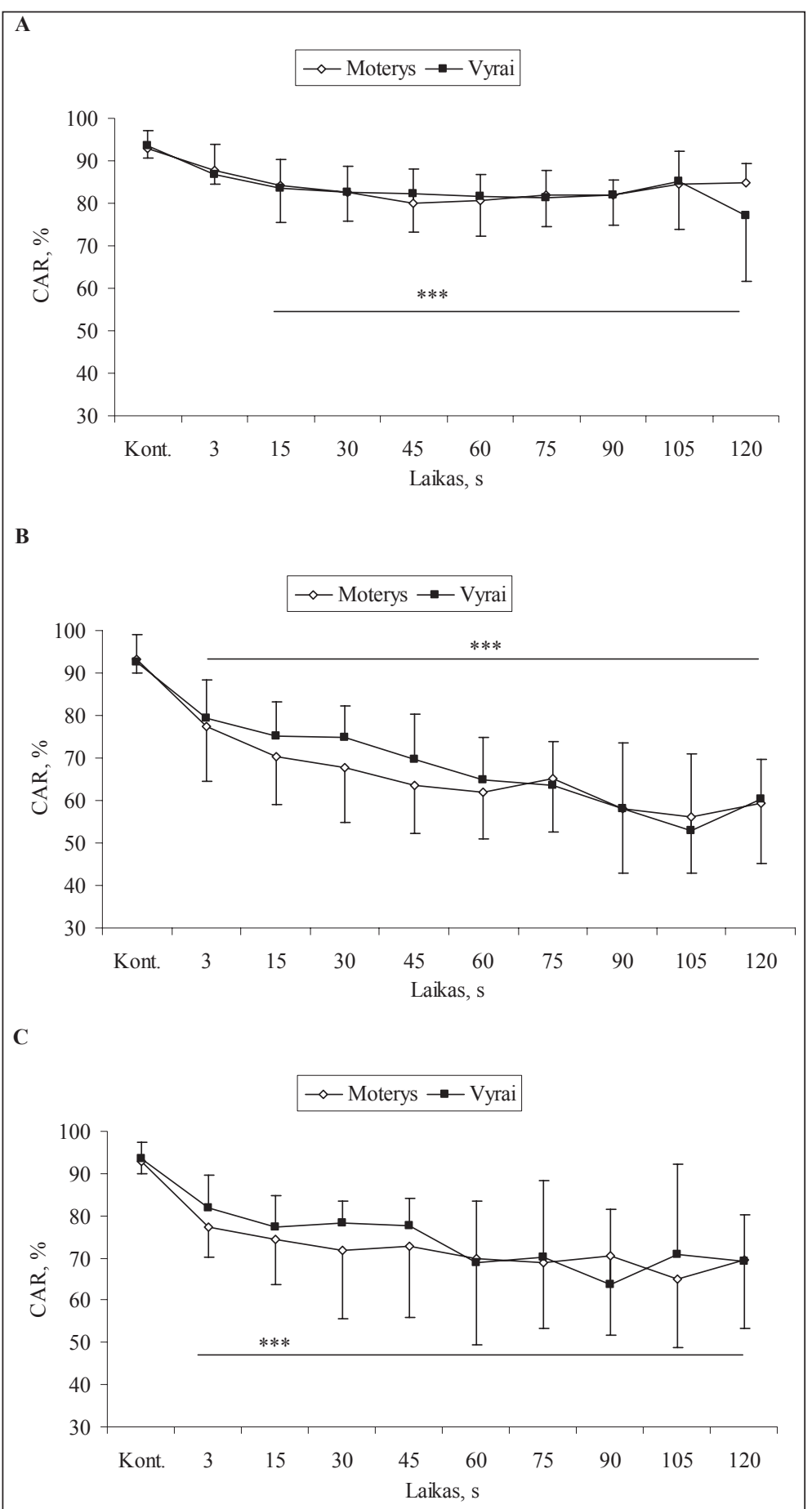

dens pusiausvyros palaikymas viduląstelineje ir užląstelinejje terpejje, nervinis laidumas, ląstelinis metabolizmas ir palaikomas kraujo tūris — osmoreguliacija bei spaudimas (Armstrong, 2000). Galima manyti, kad aklimatizuotiems žmonėms tinkamai atlikus peroralinę rehidrataciją krūvio metu turètų sumažèti dèl dehidratacijos atsiradęs centrinis nuovargis. Peroralinè rehidratacija šiek tiek sumažino ir vyrų, ir moterų rektalinę temperatūrą, ŠSD. Dẻl to sumažėjo FSI rodiklis. Manome, kad tai susiję su atgautu cirkuliuojančio kraujo kiekiu rehidratacijos metu. Dèl šios priežasties galèjo pagerèti, t. y. sulètèti širdies veikla, suma- žèti centrinis nuovargis (Wilmore, Costill, 2004). Mūsų tyrimo atveju fiziologinio terminio streso atsakas ir centrinis nuovargis galèjo sumažèti dèl geresnès aktyviai sportuojančių tiriamujų širdies ir kraujagysliu sistemos adaptacijos prie hipertermijos ir fizinių krūvių, geresnio vandens ir elektrolitu santykio prakaite, viduląstelinèje ir tarpląstelinejje terpèje (Armstrong, 2000).

Manėme, kad dèl palankesnès raumenų kompozicijos, atliekant ištvermès reikalaujantị darbą, moterų periferinis nuovargis turètų būti mažesnis nei vyrų, o dẻl mažiau veiksmingos termoreguliacijos centrinis nuovargis turètų būti didesnis, 
lyginant su vyrais. Visgi lyginant sportuojančiu vyru ir moteru MVJ bei TT-100 Hz izometrinio krūvio metu sukeltą nevalingą jègą, tenkančią vienam kilogramui tiriamujų kūno masės, visų trijų eksperimentų metu aktyviai sportuojančių vyrų ir moteru rezultatai nesiskyrè.

Galima manyti, kad fiziologinio terminio streso atsaką lemia daugybè veiksnių, tarp kurių neabejotinai yra peroraliniai skysčiu pasisavinimo fiziologiniai mechanizmai ir pasyvaus šildymo metodikos parinkimas. Fiziologinio $0,9 \% \mathrm{NaCl}$ tirpalo pasisavinimas hipertermijos metu priklauso nuo fizinių asmenų vegetacinès (termoreguliacijos), širdies ir kraujagysliu sistemų adaptacijos prie fizinių krūvių ir hipertermijos.

\section{IŠVADOS}

CAR ir santykiniai MVJ ir TT-100 Hz rodikliai tarp aktyviai sportuojančių vyrų ir moterų visų eksperimentų metu reikšmingai nesiskyrè.

Rehidratacija hipertermijos sąlygomis reikšmingai sumažino tiriamujų centrinį nuovargi, lyginant su dehidratacija hipertermijos sąlygomis. Tačiau šis rodiklis rehidratacijos ir dehidratacijos hipertermijos sąlygomis buvo nustatytas reikšmingai didesnis, lyginant su kontrolinio eksperimento reikšmėmis.

MVJ ir TT-100 Hz sukeltos jègos momento rodiklių kaita krūvio metu tarp eksperimentų reikšmingai nesiskyrè.

\section{LITERATŪRA}

Armstrong, L. E., Curtis, W. C., Hubbard, R. W. et al. (1992). Symptomatic hyponatremia during prolonged exercise in heat. Medicine \& Science in Sport \& Exercise, $25,543-549$.

Armstrong, L. E. (2000). Performing in Extreme Environments: The Importance of Dietary Sodium. Human Kinetics. P. $38-45$.

Bauman J. E. (1981). Basal body temperature: Unreliable method of ovulation detection. Fertility and Sterility, 36 (6), 729-33.

Bamman, M. M., Hill, V. J., Adams, G. R., Haddad, F. et al. (2003). Gender differences in resistance-training-induced myofiber hypertrophy among older adults. Journals of Gerontology Series A: Biological Sciences and Medical Sciences, 58, 108-116.

Behm, D., Power, K., Drinkwater, E. (2001). Comparison of interpolation and central activation ratios as measures of muscle inactivation. Muscle Nerve, 24 (7), 925-934.

Bilodeau, M. (2006). Central fatigue in continuous and intermittent contractions of triceps brachii. Muscle Nerve, 34 (2), 205-13.

Clark, B. C., Manini, T. M., The, D. J., Doldo, N. A., Ploutz-Snyder, L. L. (2003). Gender differences in skeletal muscle fatigability are related to contraction type and EMG spectral compression. Journal of Applied Physiology, 94, 2263-2272.

Coyle, E. F., Hamilton, M. A. (1990). Fluid replacment during exercise: Effects on physiological homeostasis and performance. In C. V. Gisolfi, D. R. Lamb (Eds.), Fluid Homeostasis During Exercise. Perspectives in Exercise Science and Sports Medicine, 3, 281-308.

Ditor, D. S., Hicks, A. L. (2000). The effect of age and gender on the relative fatigability of the human adductor pollicis muscle. Canadian Journal of Pharmacology, 78, 781-790.

Enoka, R. M. (2002). Neuromechanics of Human Movement. $3^{\text {rd }}$ edition. Champaign, IL: Human Kinetics.

Fulco, C., Rock, P., Muza, S. et al. (1999). Slower fatigue and faster recovery of the adductor pollicis in women matched for strength with men. Acta Physiologica Scandinavica, 167, 233-239.

Horvath, S. M., Drinkwater, B. L. (1982). Thermoregulation and the menstrual cycle. Aviation, Space and Enviro- ment Medicine, 53 (8), 790-4.

Hunter, S. K., Enoka, R. M. (2001). Sex differences in the fatigability of arm muscles depends on absoliute force during isometric contractions. Journal of Applied Physiology, 91, 2686-2694.

Kent-Braun, J. A. (1999). Central and peripheral contributions to muscle fatigue in humans during sustained maximal effort. European Journal of Applied Physiology, $80,57-63$.

Lindle, R. S., Metter, E. J., Lynch, N. A. et al. (1997). Age and gender comparisons of muscle strength in 654 women and men aged 20-93 years. Journal of Applied Physiology, $83,1581-1587$

McLellan, T. M. (1998). Sex-related differences in thermoregulatory responses while wearing protective clothing. European Journal of Applied Physiology, 78, 28-37.

Moran, D. S., Shitzer, A., Pandolf, K. B. (1999). A physiological strain index to evaluate heat stress. Ambient Journal of Physiology, 275, R 129-134.

Morrison, S. A., Sleivert, G. G., Cheung, S. S. (2004). Passive hyperthermia reduces voluntary activation and isometric force production. European Journal of Applied Physiology, 91, 729-736.

Proulx, C. I., Ducharme, M. B., Kenny, G. P. (2003). Effect of water temperature on cooling efficiency during Hyperthermia in humans. Journal of Applied Physiology, 94 (4), 1317-1323.

Rothchild, I., Barnes, A. C. (1952). Effects of dosage, and of estrogen, androgen or salicylate administration on degree of body temperature elevation induced by progesteron. Endocrinology, 50, 485-496.

Sato, K., Kang, W. H., Saga, K., Sato, K. T. (1989). Biology of sweat glands and their disorders. I. Normal sweat gland function. Journal of American Academy of Dermatology, 4, 537-565.

Staron, R. S., Hagerman, F. C. (2000). Fiber type composition of the vastus lateralis muscle of young men and women. Journal of Histochemistry \& Cytochemistry, 48, 623-629.

Thomas, M. M., Cheung, S. S., Elder, G. C., Sleivert, G. G. (2006). Voluntary muscle activation is impaired by core temperature rather than local muscle temperature. Journal of Applied Physiology, 100, 1361-1369. 
Vadopalas, K., Skurvydas, A., Brazaitis, M., et al. (2007 a). Hipertermijos ir dehidratacijos poveikis suaugusių vyru griaučių raumenų nuovargiui atliekant maksimalaus intensyvumo izometrinius pratimus. Ugdymas. Küno kultūra. Sportas, 4 (67), 87-93.

Vadopalas, K., Skurvydas, A., Brazaitis, M. et al. (2007 b). Impact of hyperthermia and degydratation on skeletal muscle of adult women performing isometric exercise of maximum intensity. Ugdymas. Kūno kultūra. Sportas, 3 (66), 48-55.

Vadopalas, K., Skurvydas, A., Brazaitis, M. et al. (2008). Hipertermijos ir dehidratacijos poveikis aktyviai sportuojančių vyrų griaučių raumenų nuovargiui atliekant maksimalaus intensyvumo izometrinius krūvius. Ugdymas. Kūno kultūra. Sportas, 2 (69), 101-108.

Wilmore, J. H., Costill, D. L. (2004). Physiology of Sport and Exercise. Human Kinetics. P. 307-330.

\title{
THE EFFECT OF DEHYDRATION AND REHYDRATION UNDER THE CONDITIONS OF HYPERTHERMIA ON CENTRAL AND PERIPHERAL FATIGUE OF MEN AND WOMEN ACTIVELY ENGAGED IN SPORTS
}

\author{
Kazys Vadopalas, Marius Brazaitis, Albertas Skurvydas, Aleksas Stanislovaitis, Nerijus Eimantas, \\ Petras Minderis, Justinas Kudrevičius \\ Lithuanian Academy of Physical Education, Kaunas, Lithuania
}

\begin{abstract}
The aim of the study was to establish the impact of dehydration and rehydration under the conditions of hyperthermia on central and peripheral fatigue of man and women actively engaged in sports. The research participants were actively engaged in sports adult males $(\mathrm{n}=10$, age $21.1 \pm 1.3$ years, body mass $70.46 \pm 6.54 \mathrm{~kg}$, and height $174 \pm 5.3 \mathrm{~cm})$ and actively engaged in sports females $(\mathrm{n}=8$, aged $21.2 \pm 2.4$ years, body mass $60.88 \pm$ $8.4 \mathrm{~kg}$, and height $170.2 \pm 4.9 \mathrm{~cm}$ ) (medium distance runners training $\geq 10 \mathrm{~h}$ a week).

Three studies were carried out - one control study and the other two - experimental. During the first experiment the bodies of the research participants experienced hyperthermia and dehydration (research participants kept their legs up to the pelvis in the bath with hot water $\left(44 \pm 1^{\circ} \mathrm{C}\right)$ for 45 minutes), and was caused $\mathrm{I}^{\circ}$ dehydratation. During the experiment, male subjects lost an average of $0.94 \pm 0.15 \mathrm{~kg}(1.33 \pm$ $0.13 \%)$, the female subjects has lost an average of $0.62 \pm 0.18 \mathrm{~kg}(1.01 \pm 0.18 \%)$ of their body weight. During the other experiment, using the same procedure of increasing hyperthermia, the organisms experienced peroral rehydration (within 1 hour every 6 min subjects were given $100 \mathrm{ml}$ (a total of with the $1000 \mathrm{ml}$ ) of $37^{\circ} \mathrm{C} \mathrm{NaCl} 0.9 \%$ solution). Men's weight increased by an average of $-0.1 \pm 0.42 \mathrm{~kg}(0.1 \pm 0.58 \%)$, while women's weight increased by an average of $-0.34 \pm 0.18 \mathrm{~kg}(0.57 \pm 0.32 \%)$ of their body weight. The load of maximum voluntary contraction (MVC) lasted for 120 seconds, every 15 seconds the muscle was stimulated by electrical impulse beam (the duration of stimulation was $250 \mathrm{~ms}$, frequency $-100 \mathrm{~Hz}$ (TT$100 \mathrm{~Hz})$ ). We registered muscle MVC torque $(\mathrm{N} \cdot \mathrm{m})$, induced involuntary muscle force - TT-100 Hz and the degree of central activation of muscle CAR.

After dehydration under the condition of hyperthermia and rehydratation under the condition of hyperthermia, the rectal males and females body temperature averagely increased by $\sim 2^{\circ} \mathrm{C}(\mathrm{p}<0.001)$. MVC, TT-100 Hz and CAR rates among men and women of all experiments did not differ significantly. Rehydration under the condition of hyperthermia significantly reduced the central fatigue of the subjects compared to dehydration under the condition of hyperthermia. But that rate was significantly higher compared to the one in the control experiment (that is to say CAR rate compared to the beginning value reduced significantly by $26,42,15 \%$ ). MVC and TT-100 Hz-induced forces change during exercise were not significantly different between the experiments.
\end{abstract}

Keywords: isometric exercises, central activation rate, rectal temperature, passive heating.

Gauta 2010 m. kovo 01 d.

Received on March 01, 2010

Priimta 2010 m. gegužès 31 d.

Accepted on May 31, 2010
Kazys Vadopalas

Lietuvos kūno kultūros akademija

(Lithuanian Academy of Physical Education)

Sporto g. 6, LT-44221 Kaunas

Lietuva (Lithuania)

Tel +370 37302671

E-mailkazysvado@yahoo.com 